\title{
Three Poems from the Alps
}

\author{
Roger Paul McConochie \\ Department of Antbropology \\ The University of Micbigan \\ Ann Arbor, MI 48109
}

In his typology of ethnographic genres, John Gatewood (1984) catalogs nine prose forms used to convey the reality of the lives of others. Yet, of all rhetorical modes, poetry may be the most immediate and moving. Indeed, if we accept the dictionary definition of poetry as "a composition designed to convey a vivid and imaginative sense of experience, characterized by the use of metaphor and other condensed forms of language," then we may discover that those whom we study are often speaking, if not always writing, poetry. If this is so, then by neglecting the poetic voice, our ethnographies may be-as Gatewood suggests- "in danger of omitting great portions of the human experience" (1984:8). Reciprocally, the inclusion within our ethnographies of poetry - both that composed by those whom we have studied ("ethnopoetry") and that which we ourselves have written ("anthropological poetry")—may serve as "meditations on our common humanity" (Fratto 1982:18).

During my three years among the German-speaking population of the Italian South Tyrol, I had occasion to discover poetry in their lives and in mine. The first of the three examples included here comes from the archives in the village of St. Anna. In recording a death in 1860 , the priest notes that the local schoolmaster and church organist had been "ein Original" whose greatest pleasures had been in composing songs and light verse. As a marginal note, the priest then inscribes one verse which this teacher had written, a prayer composed on the occasion of a religious procession in this high Alpine community.

\section{Prayer to the Mother of Mary}

Hl. Muater Anna! sollst verstehn, Wenn ma jetzt mit'n Kreuzgang gehn:

Wir bitten um Regen, net um Schnee!

HI. Muater Anna, das versteh!

Johannes Dandler

(ca. 1820-1860)

Holy Motber Anna, we'd like to make it clear

As we go on procession bere:

We're asking for rain, not for snow-

Really, Motber Anna, that's sometbing you should know!
Poetry of a more-formal composition is also wellregarded in the Tyrol. In the early years of the present century, life in the Alps was portrayed and celebrated by Sebastian Reiger in his more-than fifty novels and collections of folktales. One of his poems has achieved the status of the "Tyrolean anthem" and this is included as the second item.

\section{Tirol ist lei oans}

Tirol ist lei oans, ist a Landl, a kloans, ist a schiens, ist a feins, und dös Landl ist meins.

Mei Liab ist Tirol, ist mei Weh und mei Wohl, ist mei Gut und mei Hab, ist mei Wieg und mei Grab.

Tirol ist lei oans, wia dös Landl ist koans, in der Nah, in der Fern ist koans auf der Erdn.

Sebastian Rieger

(1887-1853)

\section{Just One Tyrol}

There is just one Tyrol, $M y$ beart and my soul; It is small, it is fine: Tyrol, you are mine.

You are ally and foe, My joy and my woe, My tapestry and loom, My cradle, my tomb.

This land of my birth Like no other on earth Is brilliant and fine: Tyrol, you are mine.

For the most part, I conducted my fieldwork interviews in a systematic manner, working from a standard set of questions and covering each topic in detail before advancing to the next. In listening to the stories of one of the older women, however, I found that her remembrances were loosely structured. When she began her account, I had thought that she was going to tell me about a certain Edward Pixner. After she had free-associated her way across a landscape of details, names, and anecdotes, I tried to bring her back to the matter at hand by asking her to provide me with more facts on the life of this one man.

Elisabeth responded on two levels. First hearing my question as, "What has become of him: where is he now?" she said that he had died. Then, after a pause, she answered as if to the question, "What then became of him: after the disappointment of unrequited love, 
did his life have rewards and satisfactions?" To this, she responded with yet another anecdote, one which said that, having lived and died, this man was now forgotten except as the subject of a barroom story in which he is the butt of the joke.

Thus, the logic of Elisabeth's discourse was not mine: Elisabeth's memories did not fit into my neat categories. However, I found that as I transcribed the conversation-"she said this, then I said that"-it took on a form which seemed true to the style in which she had spoken. Remembering the man who was surprised to learn that he had been speaking prose all his life, in making notes on my conversation with Elisabeth, I recognized with surprise that she had been speaking poetry. The option to my dismissing her structure of significance was to open myself to other ways of seeing, other forms for summing up the wisdom of a lifetime. In thus opening myself to the meanings of Elisabeth, I began to question the anthropological assumption that, through our writings, it is "we" who bestow meaning upon the lives of those whom we have designated as the objects of our studies.

Some might categorize this effort as "anthropological poetry"; others might label it an oral form of "ethnopoetry" which happens to have been recorded by the fieldworker. For myself, I would say that this poem, along with the two indigenous originals included here, served as my education that Tyrolers of every sort have long been using the forms of poetry in speaking of their lives. Together, these three pieces may suggest the potential of poetry in recording and conveying our experiences in the field, as well as recording moments within the lives of those others among whom we have lived.

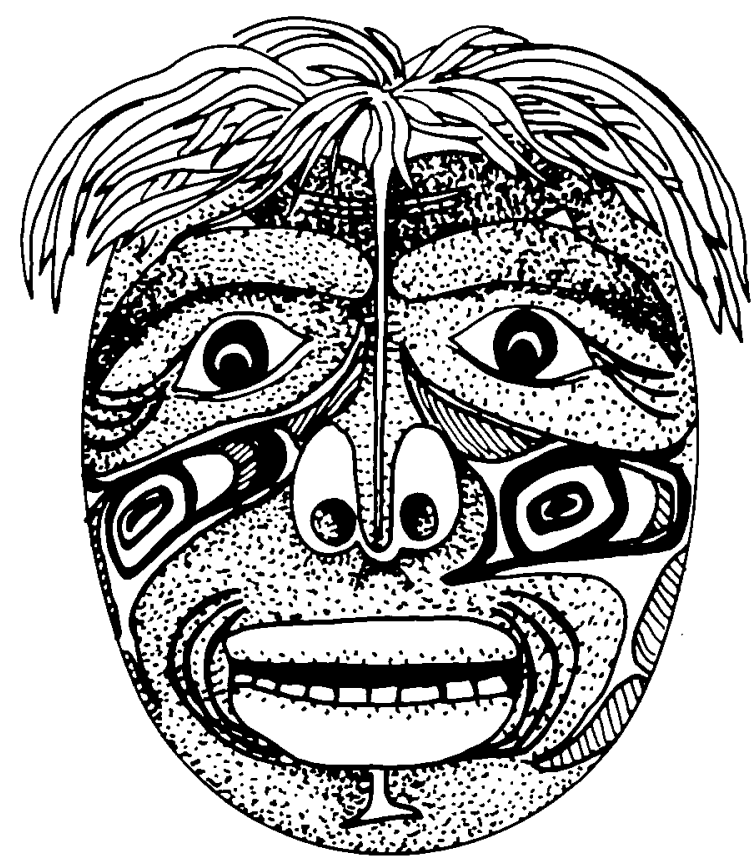

Hired Hand

"The hired man, Edward Pixner, 'Edel' he was called,

Took care of the cows in Eschbaum

When it still belonged to us.

"He loved a girl,

She married another

And went to live in Sattel-

It's a farm above Moos.

"Eschbaum was a divided farm once:

'Snowcap' the other half was called.

That farmer sold it-

That was long ago.

He went to live in Moos,

In Sattel, that we were talking about.

"Later he regretted it,

And then he used to say:

'The water in Eschbaum is better

Than the milk in Sattel';

Ja, bestimmt-

'In Eschbaum das Wasser

Ist besser als in Sattel die Milch.' "

"And Edel一what became of him?" I ask.

"Well, he died," she says. "Long dead.

"In the days when Albert and Stuber were single They and Edel would go drinking together:

Oh, they were full of foolishness!

"One evening they joined our family for the rosary, All of us in the front room on our knees.

While Edel was praying

Albert and Stuber slipped a rope 'round his ankles;

When he went to stand, he fell on his face.

"When Albert gets drinking

He still tells the story."

\section{REFERENCES CITED}

Fratto, Toni Flores. 1982. Field poetry. Antbropology and Humanism Quarterly 7(1): 16-22.

Gatewood, John B. 1984. A short typology of ethnographic genres: Or ways to write about other peoples. Anthropology and Humanism Quarterly 9(4): 5-10. 